\title{
CONVULSIONS AND HYPOGLYCEMIA DUE TO TETRAMETHYL SUCCINONITRILE INTOXICATION IN THE POLYVINYL CHLORIDE (PVC) INDUSTRY: A 4-YEAR FOLLOW-UP
}

\author{
ANGELA S. ENSSLIN ${ }^{1,2}$ and MICHAEL F. KOLLER ${ }^{3}$ \\ ${ }^{1}$ Swiss Int. Air Lines Ltd., Zurich, Switzerland \\ ${ }^{2}$ AEH Zentrum fur Arbeitsmedizin, Ergonomie und Hygiene AG, Zurich, Switzerland \\ Occupational Medicine Department \\ ${ }^{3}$ Swiss National Accident Insurance Fund (Suva), Lucerne, Switzerland \\ Occupational Medicine Department
}

\begin{abstract}
Objectives: Exposure and clinical data concerning cases of toxic convulsions and hypoglycemia due to tetramethyl succinonitrile (TMSN) exposure are reported. Material and Methods: Forty-four workers exposed to TMSN in the PVC production plant participated in occupational health medical check-ups including medical history, clinical examination and clinical chemistry. A 4-year follow-up was performed. To evaluate occupational exposure, measurements of TMSN in the ambient air as well as personal air sampling were conducted. Results: Four workers suffered from convulsions with reversible pathologic EEG and 16 other persons were hypoglycemic. Other frequent symptoms included headaches, dizziness and unpleasant taste sensations. TMSN levels had been clearly above the Swiss occupational exposure limit value (MAK). Occupational hygiene interventions resulted in a reduction of the TMSN concentration below the MAK value. TMSN related symptoms have not been observed anymore in the 4-year follow-up. Conclusion: TMSN is a convulsive substance which in humans has also a hypoglycemic effect.
\end{abstract}

Key words:

Tetramethyl succinonitrile, Neurotoxicity, Convulsion, Epilepsy, Occupational exposure, Hypoglycemia

\section{INTRODUCTION}

Tetramethyl succinonitrile (TMSN) $\left(\mathrm{C}_{8} \mathrm{H}_{12} \mathrm{~N}_{2}\right.$; CAS number 3333-52-6) is an odorless, solid substance, which is insoluble in water, but soluble in organic solvents and oil and which appears in a form of long, white crystals. Its molecular weight is $136.19 \mathrm{~g} / \mathrm{mol}$ and the melting point is $170.5^{\circ} \mathrm{C}$. TMSN is a by-product during production of polyvinyl chloride (PVC). To start the PVC polymerization process, an initiator or foaming agent is necessary. One such an initiator is the foaming agent - 2,2'-azobis(isobutyronitrile) (AZDN). After heating, TMSN is released from AZDN as the main decomposition product and is built into the polymerized plastic product. It stays in the plastic granulates, but can be released into the air by sublimation during mechanical treatment e.g. sawing, filing and grinding. At $172^{\circ} \mathrm{C}$ it desublimates and deposits as white crystals together with other condensation

Received: August 30, 2013. Accepted: January 15, 2014.

Corresponding author: A.S. Ensslin, Swiss Int. Air Lines Ltd., Occupational Medicine, P.O. Box ZRHLX/DHOM/ENAN, 8058 Zurich Airport, Switzerland (e-mail: angela.ensslin@swiss.com). 
products and deposits e.g. on various surfaces in the factory. When it deposits in pipes, these deposits can lead to obstructions and can be dangerous for the operating or cleaning staff. TMSN is absorbed by inhalation, by ingestion and through the skin [1]. No data exists on its metabolism and excretion in humans [2].

Animal experiments in rodents have shown that TMSN is a potent convulsant [3] and animals die due to asphyxia. In 1957, Reinl reported 5 cases of acute TMSN intoxication with convulsions and unconsciousness in a foam production plant. Then, a total of 16 workers were examined at the same production site. The most common symptoms were: strong headaches, nausea, vomiting, salivation, loss of appetite and disturbance of equilibrium [4]. However, no exposure data were available and it was not possible to attribute the symptoms solely to TMSN. Until today no deaths due to TMSN intoxication have been reported.

TMNS is not known to be irritant to the skin, but it can cause reddening of conjunctiva. As other structurally similar dinitriles are absorbed through the skin, TMSN was labelled with "H" skin notation for the possible dermal absorption in different official occupational exposure level (OEL) lists. In addition to its neurotoxic effect, experimental data on subchronic exposure to TMSN in rats show that kidneys and liver are target organs [5] with fatty or hyalinic degeneration and bleedings. The effects seen in the kidneys are specific for male rats and are not considered to be relevant in humans [2,5].

Animal experiments with pregnant female hamsters have revealed no teratogenic toxicity [3]. TMSN was not mutagenic in a Salmonella mutagenicity test [6]. Data are insufficient to evaluate germ cell mutagenicity, carcinogenic and sensitizing potential of TMSN [7].

Occupational exposure limits in various countries and according to various organizations are:

- Switzerland [8]-3 mg/m $\mathrm{m}^{3}$ (skin notation),

- Occupational Safety and Health Administration OSHA/

National Institute for Occupational Safety and Health NIOSH $[9,10]-3 \mathrm{mg} / \mathrm{m}^{3}$ (skin notation),
- Germany (Ausschuss fuer Gefahrstoffe AGS) [11] - $1 \mathrm{mg} / \mathrm{m}^{3}$ (no skin notation),

- Germany (Deutsche Forschungsgemeinschaft DFG) [7] - no OEL determined (skin notation),

- France [12] $-3 \mathrm{mg} / \mathrm{m}^{3}$ (skin notation).

In this report we present clinical data on 4 cases of convulsions and 16 cases of hypoglycemia of a total of 44 workers of the PVC production site. Additionally, occupational exposure data are provided. All cases of convulsions occurred between January 2006 and February 2008 when there was no occupational health surveillance.

\section{MATERIAL AND METHODS}

The affected workers were employed in a department of a middle-sized company in Switzerland where PVC is processed. The PVC boards are processed in 2 ways: the boards are sawed mechanically and then sanded manually. The machine operators' task is to insert the boards into the sawing machine, operate the machine, observe the process and stack the boards for shipment. Therefore, the operator is always in the close proximity of the machines. Specific tasks such as attending the grinding machine and sweeping dust involve a higher dust exposure.

All machines are equipped with dust exhaust. However, air in the production site is not removed to the outside. Since February 2007 exhaust air has been filtered and returned to the worksites. The production site has the following dimensions (length $\times$ width $\times$ height): $60.5 \times 24.9 \times 6.5 \mathrm{~m}$ (confection 1) and $30.7 \times 25.7 \times 6.5 \mathrm{~m}$ (confection 2) and includes 8 machines for sawing.

The study population of 44 workers (41 males, 3 females, mean age: 42 years, age range: $25-65$ years) decreased over the course of 4 years to 24 workers ( 22 males, 2 females) due to economic reasons. In 2008, 40 male subjects were machine operators and 4 other persons were mainly involved in cleaning in the production site. All workers 
wore protective clothing including cotton overalls, safety goggles, ear protection and gloves.

The mean employment time of machine operators in the PVC factory was 6.3 years (1-29 years) and 15.7 years (6-22 years) for the cleaning personnel at the time of the first occupational health intervention in February 2008.

\section{Case studies}

Case stories of the 4 workers who suffered from convulsions are summarized in Table 1 . Workers 1,2 and 3 suffered from a convulsion once in 2007/2008; whereas worker 4 had 2 episodes: one in 2006 and one in 2008 .

Table 1. Case stories of the workers who suffered from convulsions

\begin{tabular}{|c|c|c|c|c|c|}
\hline Variables & Worker 1 & Worker 2 & Worker 3 & \multicolumn{2}{|c|}{ Worker 4} \\
\hline Age (years) & 49 & 35 & 42 & \multicolumn{2}{|c|}{45} \\
\hline Sex & male & male & male & \multicolumn{2}{|l|}{ male } \\
\hline BMI & 20 & 25 & 23 & \multicolumn{2}{|c|}{25} \\
\hline Smoker & yes & no & no & \multicolumn{2}{|l|}{ no } \\
\hline Medical history & & $\begin{array}{l}\text { muscle twitch- } \\
\text { ing, neurostatus } \\
\text { unremarkable at } \\
\text { medical consulta- } \\
\text { tion } 9 \text { months be- } \\
\text { fore convulsion }\end{array}$ & $\begin{array}{l}\text { disturbance of equi- } \\
\text { librium, neurostatus } \\
\text { unremarkable at } \\
\text { medical consulta- } \\
\text { tion } 2 \text { weeks before } \\
\text { convulsion }\end{array}$ & \multicolumn{2}{|c|}{$\begin{array}{l}\text { posttraumatic epilepsia as a child with } \\
\text { subsequent anticonvulsive medication } \\
\text { until the age of } 20 \text { years }\end{array}$} \\
\hline $\begin{array}{l}\text { Years of } \\
\text { occupational } \\
\text { exposure to TMSN }\end{array}$ & 6 & 2 & 2 & \multicolumn{2}{|l|}{10} \\
\hline $\begin{array}{l}\text { Task performed } \\
\text { during the time of } \\
\text { convulsion }\end{array}$ & $\begin{array}{l}\text { after sweeping dust } \\
\text { during night shift }\end{array}$ & $\begin{array}{l}\text { while working at } \\
\text { grinding machine } \\
\text { during night shift }\end{array}$ & $\begin{array}{l}\text { while operating } \\
\text { sawing machine } \\
\text { during evening }\end{array}$ & $\begin{array}{l}\text { first convulsion } \\
\text { while operating } \\
\text { sawing machine } \\
\text { during night shift }\end{array}$ & $\begin{array}{l}\text { second convulsion } \\
\text { while sleeping at } \\
\text { home after night } \\
\text { shift }\end{array}$ \\
\hline $\begin{array}{l}\text { Observations by } \\
\text { colleagues/partner }\end{array}$ & $\begin{array}{l}\text { short period of } \\
\text { unconsciousness, } \\
\text { twitching of tongue } \\
\text { and arms }\end{array}$ & fell to the ground & $\begin{array}{l}\text { screaming, } \\
\text { unconsciousness, } \\
\text { fell to the ground, } \\
\text { tonic phase }\end{array}$ & $\begin{array}{l}\text { vomiting, fell to the } \\
\text { ground }\end{array}$ & $\begin{array}{l}\text { wild movements of } \\
\text { arms and legs }\end{array}$ \\
\hline $\begin{array}{l}\text { Clinical findings on } \\
\text { admittance to } \\
\text { hospital }\end{array}$ & $\begin{array}{l}\text { well oriented, short } \\
\text { amnesia }\end{array}$ & $\begin{array}{l}\text { short amnesia, } \\
\text { tongue bite }\end{array}$ & $\begin{array}{l}\text { slow reactions, } \\
\text { disoriented in time, } \\
\text { tongue bite }\end{array}$ & & $\begin{array}{l}\text { postictal agitation, } \\
\text { tongue bite }\end{array}$ \\
\hline Clinical chemistry & prolactin elevated & prolactin elevated & prolactin elevated & prolactin elevated & - \\
\hline $24 \mathrm{~h} \mathrm{ECG}$ & unremarkable & - & unremarkable & - & - \\
\hline Imaging of the brain & $\begin{array}{l}\text { CT, MRI } \\
\text { unremarkable }\end{array}$ & $\begin{array}{l}\text { CT, MRI } \\
\text { unremarkable }\end{array}$ & $\begin{array}{l}\text { CT, MRI } \\
\text { unremarkable }\end{array}$ & CT unremarkable & CT unremarkable \\
\hline $\begin{array}{l}\text { EEG after } \\
\text { convulsion }\end{array}$ & $\begin{array}{l}\text { unspecific changes, } \\
\text { but not typical for } \\
\text { epilepsia ( } 2 \text { days } \\
\text { after convulsion) }\end{array}$ & $\begin{array}{l}\text { theta waves, } \\
\text { delta activity } \\
\text { with vertex waves } \\
\text { ( } 4 \text { and } 12 \text { days after } \\
\text { convulsion) }\end{array}$ & $\begin{array}{l}\text { generalized spike } \\
\text { waves complexes } \\
\text { ( } 2 \text { and } 6 \text { days after } \\
\text { convulsion) }\end{array}$ & $\begin{array}{l}\text { typical postictal } \\
\text { changes }\end{array}$ & $\begin{array}{l}\text { potentials under } \\
\text { photostimulation } \\
\text { which are typical for } \\
\text { epilepsia }\end{array}$ \\
\hline $\begin{array}{l}\text { EEG follow-up } \\
\text { after 2-4 months }\end{array}$ & normal & normal & normal & & $\begin{array}{l}\text { photostimulated } \\
\text { potentials typical for } \\
\text { epilepsia }\end{array}$ \\
\hline
\end{tabular}

BMI - body mass index; TMSN - tetramethyl succinonitrile; ECG - electrocardiogram; CT - computer tomography; MRI - magnetic resonance imaging; EEG - electroencephalogram. 


\section{Exposure data}

There were no immediate complaints from the employees to the management. However, due to the repeated occurrence of convulsions among the employees, an occupational physician was consulted. After medical examinations, the occupational physician reported to the Swiss National Accident Insurance (Suva) a probable occupational disease of workers 1, 2, 3 and 4.

In February, March and April 2008 stationary air measurements and personal sampling for 12 workers at various worksites were performed by the analytical laboratory of the Swiss National Accident Insurance Fund. TMSN analysis was done according to the S155 method of the NIOSH Manual of Analytical Methods with sampling on an absorbent carbon tube, desorption and quantitative analyses by GC/FID [13].

In February 2008, TMSN concentrations were up to 12-fold above the Swiss MAK value of $3 \mathrm{mg} / \mathrm{m}^{3}$. (see Table 2). Therefore, hygienic measures were taken immediately: additional ventilation by opening doors and windows, hourly pauses, frequent cleaning of dust, mandatory respiratory protection and no drinks at worksite. In March 2008, TMSN levels were well below the MAK value (see Table 2).

Additionally, in April 2008 ambient air and personal monitoring of toluene as a general indicator for organic solvents was performed. Toluene concentrations were well below the Swiss MAK value of $190 \mathrm{mg} / \mathrm{m}^{3}$. Since April 2008 the exhaust air has been released completely through the roof to the outside.

\section{RESULTS}

\section{Medical findings}

Medical history taken by the use of a semi-structured interview in March 2008 (see Table 3) focused on the symptoms that Reinl reported in his publication on TMSN intoxication in 1957 [4]. In our study population, in 2008, the most common symptoms were: headaches $(\mathrm{N}=13)$, dizziness $(\mathrm{N}=8)$ and unpleasant taste sensations $(\mathrm{N}=7)$. Except for unpleasant taste sensations the symptoms did not correlate with the working time. Most symptoms disappeared over the course of 2 years after occupational hygienic measures had been taken.

\section{Medical examinations and follow-up}

The findings of the physical examinations are summarized in Table 4. Worker 3 left the company in 2009 for personal reasons; the other cases were still employed during the 4 year follow-up.

No relevant neurological pathologies were found during the first medical examination in 2008, except for

Table 2. Measurements of TMSN concentrations

\begin{tabular}{|c|c|c|}
\hline Date & $\begin{array}{l}\text { Stationary ambient } \\
\text { air sampling }\end{array}$ & $\begin{array}{c}\text { Personal } \\
\text { air sampling }\end{array}$ \\
\hline Before hygienic measures were taken & $\begin{array}{c}38 \mathrm{mg} / \mathrm{m}^{3} \\
\text { in recirculated exhaust air } \\
(\mathrm{N}=1)\end{array}$ & $\begin{array}{c}11 \mathrm{mg} / \mathrm{m}^{3} \\
(\mathrm{~N}=1)\end{array}$ \\
\hline $\begin{array}{l}3 \text { weeks after hygienic measures were taken, } \\
\text { day shift }\end{array}$ & $\begin{array}{l}0.25-1.92 \mathrm{mg} / \mathrm{m}^{3} \\
\text { at various work sites } \\
\qquad(\mathrm{N}=13)\end{array}$ & $\begin{array}{l}0.3-1.03 \mathrm{mg} / \mathrm{m}^{3} \\
(\mathrm{~N}=11)\end{array}$ \\
\hline $\begin{array}{l}3 \text { weeks after hygienic measures were taken, } \\
\text { night shift }\end{array}$ & $\begin{array}{l}0.1-0.3 \mathrm{mg} / \mathrm{m}^{3} \\
\quad(\mathrm{~N}=4)\end{array}$ & $\begin{array}{l}0.4-0.7 \mathrm{mg} / \mathrm{m}^{3} \\
\quad(\mathrm{~N}=19)\end{array}$ \\
\hline 6 weeks after hygienic measures were taken & $\begin{array}{c}0.1-0.9 \mathrm{mg} / \mathrm{m}^{3} \\
(\mathrm{~N}=18)\end{array}$ & $\begin{array}{c}<0.1-0.9 \mathrm{mg} / \mathrm{m}^{3} \\
(\mathrm{~N}=4)\end{array}$ \\
\hline
\end{tabular}


Table 3. Clinical symptoms of the TMSN exposed workers based on the semi-structured interviews in comparison with the findings of Reinl [4]

\begin{tabular}{|c|c|c|c|c|c|}
\hline \multirow[b]{2}{*}{ Symptom } & \multicolumn{5}{|c|}{$\begin{array}{l}\text { Workers } \\
{[\mathrm{n}(\%)]}\end{array}$} \\
\hline & $\begin{array}{c}2012 \\
(\mathrm{~N}=24, \\
\text { including } \\
2 \text { females })\end{array}$ & $\begin{array}{c}2010 \\
(\mathrm{~N}=33 \\
\text { including } \\
4 \text { females })\end{array}$ & $\begin{array}{c}2009 \\
(\mathrm{~N}=35 \\
\text { including } \\
4 \text { females })\end{array}$ & $\begin{array}{c}2008 \\
(\mathrm{~N}=44, \\
\text { including } \\
4 \text { females })\end{array}$ & $\begin{array}{c}1957[4] \\
(\mathrm{N}=16)\end{array}$ \\
\hline Dyspnea & $3(13)$ & $3(9)$ & $1(3)$ & $3(7)$ & $3(19)$ \\
\hline Extreme tiredness & $2(8)$ & $1(3)$ & $3(9)$ & $1(3)$ & $3(19)$ \\
\hline Unconsciousness & 0 & 0 & 0 & $4(9)$ & $2(13)$ \\
\hline Stomach pain & 0 & 0 & 0 & $2(5)$ & $3(19)$ \\
\hline Loss of appetite & 0 & 0 & 0 & $1(3)$ & $5(31)$ \\
\hline Weight loss & 0 & 0 & 0 & $1(3)$ & $1(6)$ \\
\hline Nausea, belching & 0 & 0 & 0 & $1(3)$ & $9(56)$ \\
\hline Unpleasant taste sensations & $1(4)$ & $1(3)$ & $3(9)$ & $7(16)$ & $3(19)$ \\
\hline Vomiting & 0 & 0 & 0 & $1(3)$ & $5(31)$ \\
\hline Hypersalivation & 0 & 0 & 0 & $1(3)$ & $7(44)$ \\
\hline Headaches $>$ twice/month & 0 & $2(6)$ & $5(14)$ & $13(30)$ & $12(75)$ \\
\hline Dizziness & 0 & 0 & $1(3)$ & $8(18)$ & 0 \\
\hline Trouble in concentrating & 0 & 0 & 0 & $1(3)$ & $2(13)$ \\
\hline Disturbance of equilibrium & 0 & 0 & 0 & $1(3)$ & $5(31)$ \\
\hline Fear & 0 & 0 & 0 & 0 & $1(6)$ \\
\hline Being easily startled & 0 & 0 & 0 & 0 & $4(25)$ \\
\hline Flaring up & 0 & 0 & 0 & 0 & $2(13)$ \\
\hline Twitching of muscles & 0 & 0 & 0 & 0 & $1(6)$ \\
\hline
\end{tabular}

Table 4. A 4-year follow-up on clinical findings of the TMSN exposed workers

\begin{tabular}{|c|c|c|c|c|}
\hline \multirow[b]{2}{*}{ Clinical finding } & \multicolumn{4}{|c|}{$\begin{array}{l}\text { Workers } \\
{[\mathrm{n}(\%)]}\end{array}$} \\
\hline & $\begin{array}{c}2012 \\
(\mathrm{~N}=24, \\
\text { including } \\
2 \text { females })\end{array}$ & $\begin{array}{c}2010 \\
(\mathrm{~N}=33 \\
\text { including } \\
4 \text { females })\end{array}$ & $\begin{array}{c}2009 \\
(\mathrm{~N}=35 \\
\text { including } \\
4 \text { females })\end{array}$ & $\begin{array}{c}2008 \\
(\mathrm{~N}=44, \\
\text { including } \\
4 \text { females })\end{array}$ \\
\hline Blood pressure $>140 / 90 \mathrm{~mm} \mathrm{Hg}$ & $5(21)$ & $9(27)$ & $7(20)$ & $8(18)$ \\
\hline \multicolumn{5}{|l|}{ Overweight (BMI) } \\
\hline$>25-30$ & $11(46)$ & $14(42)$ & $14(40)$ & $18(41)$ \\
\hline$>30-35$ & $5(21)$ & $6(18)$ & $4(11)$ & $4(9)$ \\
\hline$>35$ & 0 & $1(3)$ & $1(3)$ & 0 \\
\hline
\end{tabular}


Table 4. A 4-year follow-up on clinical findings of the TMSN exposed workers - cont.

\begin{tabular}{|c|c|c|c|c|}
\hline \multirow[b]{2}{*}{ Clinical finding } & \multicolumn{4}{|c|}{$\begin{array}{l}\text { Workers } \\
{[\mathrm{n}(\%)]}\end{array}$} \\
\hline & $\begin{array}{c}2012 \\
(\mathrm{~N}=24, \\
\text { including } \\
2 \text { females })\end{array}$ & $\begin{array}{c}2010 \\
(\mathrm{~N}=33 \\
\text { including } \\
4 \text { females })\end{array}$ & $\begin{array}{c}2009 \\
(\mathrm{~N}=35 \\
\text { including } \\
4 \text { females })\end{array}$ & $\begin{array}{c}2008 \\
(\mathrm{~N}=44, \\
\text { including } \\
4 \text { females })\end{array}$ \\
\hline Eczema (hands) & $1(4)$ & $3(9)$ & $4(11)$ & $2(5)$ \\
\hline Hearing loss (screening by finger rub) & $1(4)$ & $2(6)$ & $2(6)$ & $5(11)$ \\
\hline Differences of peripheral reflexes (left/right) & $6(25)$ & $6(18)$ & $5(14)$ & $10(23)$ \\
\hline Loss of sensation of touch on the lower legs & $1(4)$ & 0 & 0 & 0 \\
\hline Slightly reduced vibratory sensation (measured by pitchfork) & $7(29)$ & $3(9)$ & $11(31)$ & $7(16)$ \\
\hline Tremor & $2(8)$ & $1(3)$ & 0 & 0 \\
\hline Pathological Romberg test & $1(4)$ & $1(3)$ & $2(6)$ & $2(5)$ \\
\hline
\end{tabular}

Abbreviation as in Table 1.

a pathological electroneurography and sensory evoked potentials in worker 4 , in the case of which a demyelinating polyneuropathy was suspected. During the 4-year followup, a remarkable loss of sensation of touch of the lower legs was observed in worker 4.

Clinical chemistry consisted in blood cell count (QBC Diagnostics), liver function (AST, ASL, GGT), kidney function (serum creatinine), blood glucose, serum cholesterol (all measured with Reflotron, Roche) and urine analysis screening (Combur-test, Roche).

In March 2008, 23 workers were normoglycemic (3.3-6.05 mmol/1), 16 workers were hypoglycemic ( $<3.3 \mathrm{mmol} / \mathrm{l})$ and 3 workers were hyperglycemic (> $6.05 \mathrm{mmol} / \mathrm{l}$; of which 2 with preexisting diabetes). All follow-up blood glucose levels were in the normal range. The 4 cases with convulsions had normal blood sugar levels on admittance to the hospital and at all times during the follow-up.

Elevated GGT (> $71 \mathrm{IU} / \mathrm{ml}$ ) was observed in 2 workers (309 IU/ml, elevated levels known before employment in PVC production; $168 \mathrm{IU} / \mathrm{ml}$, obese diabetic worker).
Kidney function measured by serum creatinine was in the normal range, no proteinuria was observed (Combur-test).

\section{DISCUSSION}

In a PVC processing factory with 44 workers, we have observed 4 people experiencing convulsions within 2 years. Ambient monitoring revealed TMSN concentrations up to $38 \mathrm{mg} / \mathrm{m}^{3}$, which is more than 12 -fold over the Swiss occupational exposure limit (MAK value) and personal air samples were nearly 4 times higher than the MAK value. As the TMSN concentrations were very high and the clinical findings in line with the literature about TMSN, no other substances were monitored. The 4 workers did not take any drugs or alcohol which could have influenced the effect of TMSN.

All employees who suffered from convulsions had normal blood glucose levels, which shows that their seizures were not correlated with hypoglycemia. However, 16 other workers showed hypoglycemia with blood sugar concentrations $<3.3 \mathrm{mmol} / \mathrm{l}$, without other relevant clinical symptoms. 
After taking occupational hygienic measures TMSN concentrations decreased below the MAK value of $3 \mathrm{mg} / \mathrm{m}^{3}$. After 3 weeks they were below $1.92 \mathrm{mg} / \mathrm{m}^{3}$ and after 6 weeks they were below $0.9 \mathrm{mg} / \mathrm{m}^{3}$, which is even below the German (AGS) value of $1 \mathrm{mg} / \mathrm{m}^{3}$ [11]. This value is based on a study on dogs that experienced a slight increase of liver weight [11]. Our case supports the safeness of this OEL also in humans with respect to convulsions. None of the workers has experienced any convulsions or hypoglycemia throughout the 4-year follow-up until today.

To the best of our knowledge, this is the first report describing a hypoglycemic effect of TMSN in humans and it is the first publication with clinical findings related to TMSN in combination with exposure data during a follow-up lasting 4 years. Interestingly, the reduced blood glucose levels in rats subchronically exposed to TMSN have been reported before [5]. The only reported hypoglycemic effect of nitriles in humans known to us, is that of vildagliptin an antidiabetic drug. Vildagliptin belongs to the group of dipeptidyl peptidase-4 (DPP-4) inhibitors [14]. It covalently binds to the catalytic site of DPP-4 via its nitrile group and blocks DPP-4 activity and thus lowers the blood sugar level. Whether the blood sugar lowering mechanism of vildagliptin is the same as the one seen in our cases of workers exposed to TMSN remains unknown.

In the case of the 4 workers, the high TMSN levels led to convulsions and unconsciousness. This finding is supported by EEGs that showed pathologic changes, however, not always typical for epilepsy. They were fully reversible in the 3 cases. The fourth person with remaining pathologic signs in the EEG had suffered from posttraumatic epilepsy as a child and had been free of symptoms for many years. Possibly the documented EEG changes were related to his childhood epilepsy. Based on the occupational hygienist's evaluation, no other ambient toxins were of importance. There was no evidence of other causes for the convulsions, e.g. other toxins or alcohol. Clinical chemistry (blood cell count, liver enzymes, creatinine, blood sugar and urine analysis) of the 4 persons who suffered from convulsions on admittance to the hospital did not reveal any significant pathologic findings. However, lack of sleep remains a possible co-factor in these shift workers. In the meantime, all of the 4 cases were recognized by the Swiss National Accident Insurance Fund (Suva) as occupational diseases.

TMSN is known to be highly neurotoxic in the case of animals [5]. Concerning the neurotoxic potential of TMSN in humans, our findings are in line with Reinl's who reported 5 cases of toxic convulsions in TMSN exposed workers with similar tasks as in this report [4]. Reinl, however, did not report exposure levels. Interestingly, our observation concerning one convulsive episode occurring after a time lag of a few hours at home was also described by Reinl [4]. Occupational history of all the exposed workers including 3 of the 4 cases with convulsions hinted at unspecific health complaints related to TMSN before the occurrence of seizures. Two of the 4 workers who suffered from convulsions had actually consulted a general practitioner because of muscles twitching and a disturbed equilibrium before the convulsions occurred. Common symptoms were headaches, dizziness and unpleasant taste sensations which are known to be possibly induced by TMSN but did not show a clear time work-relatedness to the occupational exposure to TMSN except for unpleasant taste sensations. However, due to the remarkable improvement of these symptoms in the course of time it is convincing that these unspecific symptoms were TMSN induced. Reinl reported mostly headaches, nausea and salivation [4].

Slightly reduced vibratory sensation as diagnosed with a tune fork was found in 7 persons. Over the course of time no deteriorations were found and these minute findings were evaluated as clinically insignificant along with the slight abnormalities in coordination, slight differences in peripheral reflexes and tremor. However, worker 4 was diagnosed with beginning polyneuropathy showing a reduced vibratory sensation increasing in the course of time and recent impressive loss of sensation of touch on the 
lower legs. In 2008 electroneurography implicated a symmetric demyelinating polyneuropathy for which there were hints in the sensory evoked potentials. This observation raises the question of toxic polyneuropathy as other causes for polyneuropathy such as diabetes, alcohol and pharmaceutical drugs were excluded. There is no literature supporting TMSN induced polyneuropathy and this pathology appeared 4 years after the high TMSN exposure. Thus, causal relationship remains uncertain and clinical progression needs to be followed up carefully.

Our data do not show any evidence for a hepatotoxic or nephrotoxic potential of TMSN at the reported concentrations based on the serum transaminsase levels, serum creatinine and absence of proteinuria.

\section{CONCLUSION}

TMSN is a convulsive substance which in humans also seems to have a hypoglycemic effect.

\section{ACKNOWLEDGEMENTS}

The authors thank Prof. Philipp Hotz for valuable discussions.

\section{REFERENCES}

1. International Chemical Safety Card 1121 [cited 2012 Oct 12]. Available from: http://www.inchem.org/documents/icsc/icsc/ eics1121.htm.

2. Tetramethyl succinonitrile. Health-based Reassessment of Administrative Occupational Exposure Limits. No. 2000/15OSH/041. Commitee of the Health Council of the Netherlands, The Hague 2002.

3. Doherty PA, Smith RP, Ferm VH. Comparison of the teratogenic potential of two aliphatic nitriles in hamsters: succinonitrile and tetramethylsuccinonitrile. Fund Appl Toxicol. 1983;3:41-8, http://dx.doi.org/10.1016/S0272-059AC0 (83)80171-7.
4. Reinl W. [Illnesses due to tetramethyl succinonitrile (TMSN) in the foam industry]. Archiv Fuer Toxikol. 1957;16(6): 367-80. German.

5. Johannsen FR, Levinskas GJ. Subchronic toxicity of tetramethylsuccinonitrile. Fundam Appl Toxicol. 1986;7(1):41-8, http://dx.doi.org/10.1016/0272-0590(86)90195-8.

6. Ishiwata $\mathrm{H}$, Inoue T, Yoshihira K, Nohmi T, Ishidate Jr M. Lack of mutagenicity of tetramethylsuccinonitrile in Salmonella typhimurium TA strains. Bull Natl Inst Hyg Sci. 1987;105:100-1.

7. Deutsche Forschungsgemeinschaft. The MAK Collection for Occupational Health and Safety. [Tetramethyl succinonitrile]. Wiley Online Library; 2001. p. 1-6. German.

8. Suva. [Occupational Exposure Limits]. Lucerne: Suva; 2013. German.

9. National Institute of Occupational Safety and Health. Pocket Guide to Chemical Hazards [cited 2014 Jan 3]. Available from: http://www.cdc.gov/niosh/npg/npgd0604.html.

10. Occupational Safety \& Health Administration. Table Z-1 Limits for Air Contaminants [cited 2014 Jan 3]. Available from: https://www.osha.gov/pls/oshaweb/owadisp.show_ document?p_table $=$ standards\&p_id $=9992$.

11. Ausschuss für Gefahrstoffe. [Tetramethyl succinonitrile. Rationale to TMSN in TRGS 900]. BAuA [cited 2014 Jan 3]; 2007. p. 1-7. Available from: http://www.baua.de/de/Themen-von-AZ/Gefahrstoffe/TRGS/Arbeitsplatzgrenzwerte.html. German.

12. Institut national de recherche et de sécurité. [Occupational exposure limits in France]. INRS; 2012. French.

13. National Institute of Occupational Safety and Health. NIOSH Manual of Analytical Methods. 2nd ed. Cincinnati: DHEW (NIOSH) publication No. 77-157-C. Vol. 3. US Dept of Health, Education and Welfare, Public Health Service, Center of Disease Control; 1977.

14. Ahrén B, Schweizer A, Dejager S, Villhauer EB, Dunning BE, Foley JE. Mechanisms of action of the dipeptidyl peptidase-4 inhibitor vildagliptin in humans. Diab Obes Metab. 2011;13(9):775-83, http://dx.doi.org/10.1111/j.14631326.2011.01414.x.

This work is available in Open Access model and licensed under a Creative Commons Attribution-NonCommercial 3.0 Poland License - http://creativecommons.org/ licenses/by-nc/3.0/pl/deed.en. 